\title{
Preclinical and manifest diabetes mellitus in young patients with Friedreich's ataxia: no evidence of immune process behind the islet cell destruction
}

\author{
E.J.Schoenle ${ }^{1}$, E.J. Boltshauser ${ }^{1}$, S. Baekkeskov ${ }^{3}$, M.Landin Olsson ${ }^{4}$, T.Torresani ${ }^{1}$ and A.von Felten ${ }^{2}$ \\ ${ }^{1}$ Department of Paediatrics, and ${ }^{2}$ Department of Medicine, University of Zuerich, Switzerland, \\ ${ }^{3}$ Hagedorn Research Laboratory, Gentofte, Denmark, and ${ }^{4}$ Department of Medicine, University of Lund, Malmö, Sweden
}

\begin{abstract}
Summary. Friedreich's ataxia is known to be associated with diabetes mellitus in up to $20 \%$ of the patients. However, type, development and course of diabetes mellitus are not well characterised. We report on 3 patients ( 2 female and 1 male, age 13-20 years) with the combination of Friedreich's ataxia and diabetes mellitus. Diabetes mellitus was characterised as follows: (1) it was strictly insulin-dependent and ketosis-prone, (2) the average insulin requirement was $1 \mathrm{U} / \mathrm{kg}$ body weight, (3) the HLA haplotype was not typical of Type 1 (insulin-dependent) diabetes mellitus, (4) there were no positive immune parameters typical of Type 1 diabetes at the clinical onset of diabetes mellitus and (5) there was no remission. To evaluate a preclinical phase as in common autoimmune Type 1 diabetes, i.v. glucose tolerance tests $(0.5 \mathrm{~g}$ glucose $/ \mathrm{kg}$ body weight) were performed in 8 patients with Friedreich's ataxia
\end{abstract}

without diabetes mellitus. Seven patients had normal early phase insulin response. In contrast, the glucose disappearance rate was slow in 4 and normal in 3 patients. One of the 8 patients showed a prediabetic metabolic state: the early-phase insulin response was abolished and the glucose disappearance rate was abnormal. The results suggest that diabetes in Friedreich's ataxia is caused by a loss of islet cells similar to common Type 1 diabetes but without HLA-association and without serologic evidence for autoimmune destruction of the islet cells.

Key words: Type 1 (insulin-dependent) diabetes mellitus, Friedreich's ataxia, HLA, first phase insulin secretion, islet cell antibodies.
Friedreich's ataxia (FA) is a progressive neurodegenerative disorder whose first clinical signs of ataxia usually occur in the second half of the first decade. The inheritance is autosomal recessive with a carrier frequency of about $1 / 100[1,2]$. The prevalence has been estimated to be about 1 in $50,000[3,4]$. The gene locus of FA has recently been located on the short arm of chromosome 9 [5].

FA is characterized by degeneration of spinocerebellar tissue and large myelinated nerve fibers in the dorsal root ganglia and cardiomyopathy. In addition, diabetes mellitus has been found to be associated with FA in up to $20 \%[1,6,7]$. However, type, development and course of diabetes mellitus is not well characterized in the literature.

Understanding of the pathogenesis of common Type 1 (insulin-dependent) diabetes has increased rapidly in recent years. HLA DR3/DR4 association [8], high incidence of appearance of antibodies against islet cells, insulin and many other proteins [9] and the possibility of interrupting the disease at an early stage by immunosuppressive therapy point to an autoimmune disorder as the cause of B cell destruction [10].
This study was designed to determine whether clinical and laboratory features of diabetes mellitus associated with FA are comparable to those seen in common autoimmune Type 1 diabetes. Three patients with the combination of diabetes mellitus and FA and one with FA and a preclinical diabetic metabolic state are reported. In addition, insulin and glucose metabolism are described in 8 patients with FA without diabetes mellitus.

\section{Patients and methods}

All patients and their parents gave their consent after thorough information. There were no known additional cases of FA or diabetes mellitus in the families involved in the study. Three patients with FA and diabetes mellitus were investigated. In 8 patients who fulfilled neurological criteria of FA [11], but without clinical signs of any disturbances of glucose metabolism, intravenous glucose tolerance tests (i.v. GTTs) were performed. The patients were asked to eat a regular diet with normal quantities (at least $200 \mathrm{~g}$ ) of carbohydrates during the days before the test, which was performed after an overnight fast. They were nonobese and in a good nutritional condition. Glucose $(0.5 \mathrm{~g}$ per $\mathrm{kg}$ body weight) was administered i.v. within $2 \mathrm{~min}$. Blood samples were collected $5 \mathrm{~min}$ before and 1, 3, 5, 10, 20,30, 45, $60 \mathrm{~min}$ 
after administration of glucose. Glucose, insulin and C-peptide were determined in duplicate.

In addition, $\mathrm{Hb}_{1}$ and islet cell antibodies were determined in each patient. $\mathrm{HbA}_{1}$ was measured by a commercial kit (Boehringer, Mannheim, FRG) with normal values below $8 \%$. The glucose disappearance rate $(K=\ln : t / 2)$ was calculated according to Hürter et al. [12]. Islet cell antibodies were analysed with an indirect immunofluorescence method [13]. Autoantibodies to the $64 \mathrm{~K}$ islet cell protein were performed using both purified human islet [14] and rat islet cell membrane proteins.

HLA-A, -B, and -DR typing was performed in patients with FA and DM and in one FA patient without DM (patient 4). HLA-A-, -B-typing was performed by standard techniques. HLA-DR, -DQw specificities were determined on nylon wool separated B cells by the two-stage microcytotoxicity test using 120 antisera.

\section{Results}

The clinical and immunological data of the patients with the combination of FA and diabetes mellitus are summarized in Table 1, those of the patients without diabetes mellitus in Table 2. No clinical data about glucose metabolism were available before the onset of diabetes mellitus. In all patients the first clinical signs of FA occurred between 4 and 10 years of age. Cardiomyopathy was diagnosed at the beginning or soon after diagnosis of FA by electrocardiography and/or echocardiography.

Table 1. Patients with Friedreich's ataxia and diabetes mellitus: relevant clinical data

\begin{tabular}{lcccc}
\hline Patient number & 1 & 2 & 3 & 4 \\
\hline Sex & $\mathrm{f}$ & $\mathrm{m}$ & $\mathrm{f}$ & $\mathrm{f}$ \\
Age (years) & 13 & 20 & 14 & 23 \\
Onset Friedreich's ataxia (age) & 5 & 6 & 5 & 5 \\
Cardiomyopathy & yes & yes & yes & see \\
Wheelchair (age) & 10 & 10 & 10 & Table 2 \\
Onset diabetes (age) & 11 & 16 & 12 & \\
Remission of diabetes & no & no & no & \\
Insulin requirement (U/kg) & 1.3 & 0.9 & 1.1 & \\
Ketoacidosis at diagnosis diabetes & yes & yes & yes & \\
Antibodies at diagnosis diabetes & & & & \\
$\quad$ Against islet cells & no & no & no & no \\
Against 64K protein & no & no & no & no \\
HLA A & $2 / 3$ & $2 / 3$ & $2 / 30$ & $10 / 26$ \\
HLA B & $7 / 27$ & $7 / 17$ & $21 / 27$ & $7 / 16$ \\
HLA DR & $4 /$ w6 & $3 /$ w10 & $1 / 7$ & $2 / \mathrm{w} 52$ \\
\hline
\end{tabular}

All three patients with FA and diabetes mellitus (Table 1) showed ketoacidosis at the beginning of diabetes mellitus. No remission occurred after starting insulin treatment and the insulin requirement was close to $1 \mathrm{U} / \mathrm{kg}$ body weight up to the present time in all of them. Fasting $\mathrm{C}$-peptide values were unmeasurably low $(<50 \mathrm{pmol} / 1)$. Antibodies against islet-cells were not detected at clinical onset of diabetes mellitus in the three patients and antithyroid antibodies have so far remained negative. In addition, antibodies against the $64 \mathrm{~K}$ membrane protein of pancreatic islets were not found within the first six months after diagnosis of diabetes mellitus was made.

In the other 8 patients (Table 2), no signs of manifest diabetes mellitus were detected in routine tests (no glucosuria, normal fasting blood glucose concentration). Therefore, an i.v. GTT was performed. Figure 1 shows the glucose disappearance rate $(\mathrm{K})$ in these patients. In 5 of them, the i.v. GTT was abnormal: The K-value ranged between 1.0 and 1.4 in 4 patients (impaired glucose tolerance) and it was in the diabetic range $(\mathrm{K}=0.13)$ in patient 4 . In all patients, no antibodies against islet cells and the $64 \mathrm{~K}$ membrane protein of pancreatic islets could be detected. The $\mathrm{Hb} \mathrm{A}_{1}$ was normal in all patients including patient 4 , who were without manifest diabetes (Table 2).

Irrespective of the glucose disappearance rate, the sum of 1- and 3-min insulin-values was in the normal range between $759 \mathrm{pmol} / 1$ and $1659 \mathrm{pmol} / 1$ $(1172 \pm 307)$. This is between 10th and 90th percentile of normal control subjects [15].

Therefore, the early phase insulin secretion was normal in all patients with FA except in patient 4 . She showed an abolished early phase insulin secretion (Figs. 2 and 3) and a sum of the 1- and 3-min value of only $222 \mathrm{pmol} / \mathrm{l}$, which is far below the 1 st percentile of normal control subjects.

\section{Discussion}

In patients with $\mathrm{FA}$, two different disturbances in glucose metabolism exist. Insulin-dependent diabetes mellitus is associated in up to $20 \%$ of the patients. Besides this, an abnormal glucose tolerance without insulin

Table 2. Patients with Friedreich's ataxia (FA) without diabetes mellitus: relevant clinical data

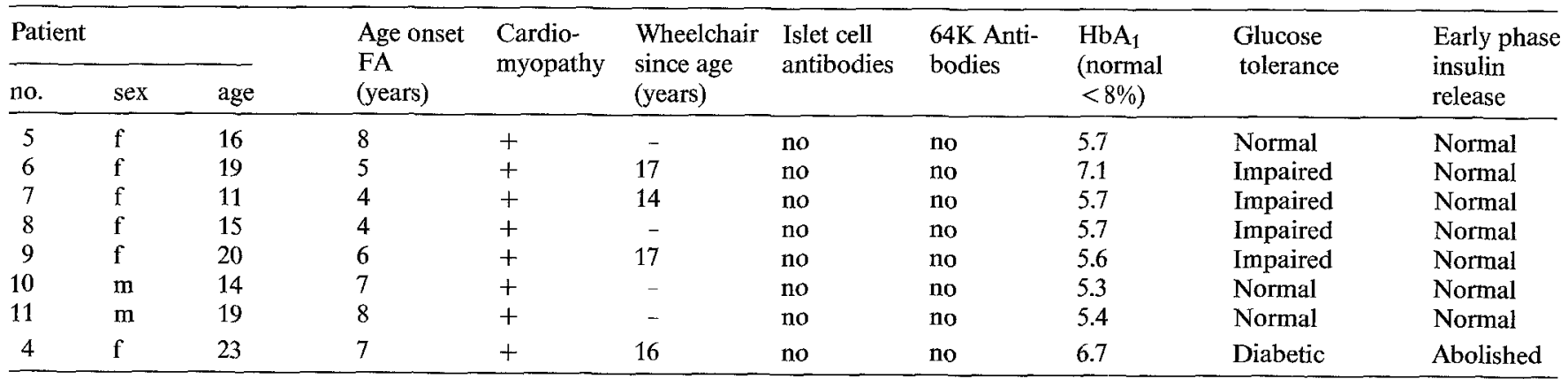


deficiency is perhaps found in a majority of patients with FA.

Common Type 1 diabetes is caused by a destruction of the B cells in the pancreas by mechanisms which seem to be autoimmune in character $[10,16]$. Recent in vitro data suggest that the B cell destruction in Type 1 diabetes could be mediated by cytokines such as interleukin-1 produced by infiltrating mononuclear cells [17].

Our data suggest that insulin-dependent diabetes mellitus in FA can be distinguished from the common autoimmune Type 1 diabetes of young people: (1) Elevated antibodies against islet cells and the $64 \mathrm{~K}$ islet cell membrane protein were not found. However, in autoimmune Type 1 diabetes, such antibodies are found at time of diagnosis in up to $90 \%$. (2) The HLA-typing in the patients with FA and diabetes mellitus was not typical of Type 1 diabetes. In more than $95 \%$ of patients with Type 1 diabetes HLA type DR3 and/or DR4 are found (versus about $40 \%$ in the normal population) whereas HLA-types DR2, DR5 and B7 are negatively associated with Type 1 diabetes [8]. None of our patients fitted clearly into this pattern. The two patients positive for DR4 (patient 1) and DR3 (patient 2) were also positive for HLA B7, patient 3 did not show HLAtype DR3 or DR4 but the only weakly positively associated DR1 and patient 4 even showed DR2 and B7, HLA types that are unusual in Type 1 diabetes.

Despite the low number of investigated patients the results suggest that insulin-dependent diabetes mellitus in FA is not caused by autoimmune destruction of islet cells similar to Type 1 diabetes.

Recent data show that islet cell antibodies, $64 \mathrm{~K}$ antibodies and islet-cell-destruction can precede clinical onset of diabetes by several years $[14,18]$. It has been shown that in these preclinical situations, peak insulin response to an i.v. glucose bolus was progressively reduced although glucose tolerance was still normal. This has been named pre-Type 1 diabetes [19].

The absent first phase insulin secretion in patient 4 suggests, that a similar preclinical situation exists in FA. Our three patients with FA, who finally showed an acute onset of diabetes with ketoacidosis, were without partial or complete remission after starting insulin therapy, which would be common in Type 1 diabetes. From this, one may conclude that diabetes mellitus in FA becomes manifest after loss of the endocrine function and probably histologic absence of B cells only. This assumption is supported by a report [20], where no, or very few, small islets were observed in two pancreases of patients with FA and insulin-dependent diabetes mellitus. Therefore, the question arises, for which reason the B cell loss occurs.

In this respect, it has to be considered that other organs (spinocerebellar centres and cardiac cells) undergo degeneration or destruction of cells in FA. The heart disease has been shown [21] to be due to abnormalities of myocardial cells with hypertrophy, fibrosis and pleo-

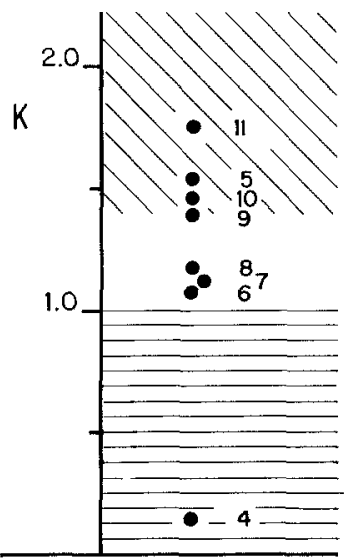

Patient number

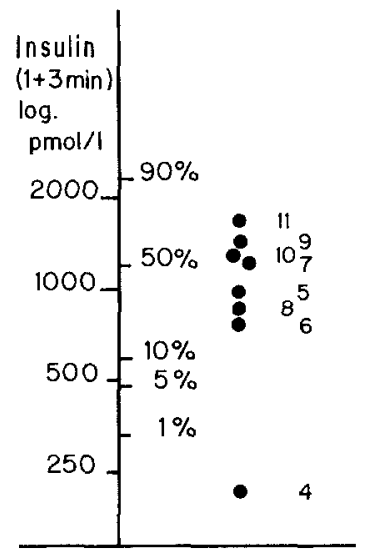

Patient number
Fig.1. Glucose disappearance rate without manifest diabetes mellitus. The numbers of the patients are as in Table 2. $\mathrm{K}=\ln (\mathrm{t} / 2)$ in 8 patients with Friedreich's ataxia

Fig. 2. Early phase insulin secretion (sum of $1+3$ min value) after an i.v. glucose bolus ( $0.5 \mathrm{~g}$ per $\mathrm{kg}$ body weight) in 8 patients with Friedreich's ataxia without manifest diabetes mellitus. The numbers of the patients are as in Table 2 . The percentage scale refers to the $10^{\text {th }}$ and $90^{\text {th }}$ percentile of normal control subjects

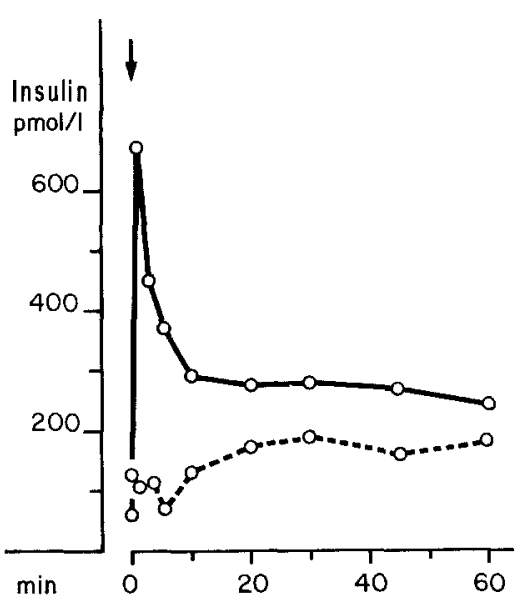

Fig. 3. Abolished (prediabetic) and normal early phase insulin secretion after an i.v. glucose bolus in 2 patients with Friedreich's ataxia without manifest diabetes mellitus. The prediabetic curve refers to patient number 4 in Table 2

morphic nuclei, degeneration of neuronal cells in nerves and ganglia and lesions of small and large coronary arteries. A more general molecular disorder has been postulated as a cause of these changes [21]. A link or common factor responsible for cell degeneration in different organs of patients with FA is therefore conceivable.

B cell destruction and consecutive insulin-dependent diabetes mellitus in some patients with FA has to be separated from impaired glucose tolerance without abnormality of insulin secretion. In 4 of 8 tested pa- 
tients with FA, an impaired glucose disappearance rate in the i.v. GTT was found, whereas the first phase insulin secretion was normal. This points to peripheral resistance to insulin. Our results are in agreement with those of Khan et al. [22], who recently demonstrated decreased insulin binding in monocytes of patients with FA and glucose intolerance.

However, peripheral resistance to glucose or insulin might be a common feature of neurologic or neuromuscular disease, since carbohydrate intolerance, which might be due to a progressive loss of muscle mass, has been shown to be present in several neuromuscular diseases such as muscular dystrophies, spinal muscular atrophies, myotonic dystrophy, Refsum's disease and others, including FA [22, 23]. Insulin-dependent diabetes mellitus is not a common feature of neuromuscular disorders but is often associated with FA.

Our results indicate, that diabetes mellitus in Friedreich's ataxia is caused by a loss of insulin-producing islet-cells similar to that in common Type 1 diabetes, but without HLA-association and no serologic evidence for autoimmune destruction of the islet cells.

Acknowledgements. We thank Drs. M.Zachmann, A.Prader and A. Fanconi for discussions and comments on the manuscript, and Dr. R. Zurbruegg for adding patient 8 . This study was supported by the Swiss National Science Foundation, Grants No.3.740-0.85 and 3.8800.86 .

\section{References}

1. Harding AE (1981) Friedreich's ataxia: a clinical and genetic study of 90 families with an analysis of early diagnostic criteria and intrafamilial clustering of clinical features. Brain 104: $589-620$

2. Andermann E, Remillard GM, Goyer C, Blitzer M, Andermann F, Barbeau A (1976) Genetic and family studies in Friedreich's ataxia. Can J Neurol Sci 3: 287-301

3. Harding AE, Zilkha KJ (1981) 'Pseudo-dominant' inheritance in Friedreich's ataxia. J Med Genetics 18: 285-287

4. Romeo G, Menozzi P, Ferlini A, Fadda S, Di Donato S, Uziel G, Lucci B, Capodaglio L, Filla A, Campagnella G (1983) Incidence of Friedreich's ataxia in Italy estimated from consanguineous marriages. Am J Human Genet 35: 523-529

5. Chamberlain S, Shaw J, Rowland A, Wallis J, South S, Nakamura Y, von Gabain A, Farrall M, Williamson R (1988) Mapping of mutation causing Friedreich's ataxia to human chromosome 9. Nature 334: 248-250

6. Thorén C (1962) Diabetes mellitus in Friedreich's ataxia. Acta Paediatr [Suppl.] 135: 239-247

7. Shapcott D, Melancon S, Butterworth RF, Khoury K, Collu R, Breton G, Geoffroy G, Lemieux B, Barbeau A (1976) Glucose and insulin metabolism in Friedreich's ataxia. Can J Neurol Sci 3: 361-364

8. Platz P, Jakobsen BK, Morling N, Ryder LP, Svejgaard A, Thomsen M, Christy M, Kromann H, Benn J, Nerup J, Green A, Hauge
M (1981) HLA-D and -DR Antigens in genetic analysis of insulindependent diabetes mellitus. Diabetologia 21: 108-115

9. Drell DW, Notkins AL (1987) Multiple immunological abnormalities in patients with Type 1 (insulin-dependent) diabetes mellitus. Diabetologia 30: 132-143

10. Lernmark $\AA$ (1985) Molecular biology of Type 1 (insulin-dependent) diabetes mellitus. Diabetologia 28: 195-203

11. Geoffroy G, Barbeau A, Breton G, Lemieux B, Aube M, Leger C, Bouchard JP (1976) Clinical description and roentgenologic evaluation of patients with Friedreich's ataxia. Can J Neurol Sci 3: 279-286

12. Hürter P, Barth N, Bierich JR (1969) Der i.v.-Glucosetoleranztest bei stoffwechselgesunden und diabetischen Kindern. Monatsschr Kinderheilkd 117: 518-522

13. Landin Olsson M, Sundkvist G, Lernmark Å (1987) Prolonged incubation in the two-colour immunofluorescence test increases the prevalence and titres of islet cell antibodies in Type 1 (insulin-dependent) diabetes mellitus. Diabetologia 30: 327-332

14. Baekkeskov S, Landin M, Kristensen JK, Srikanta S, Bruining GJ, Mandrup-Poulsen T, de Beaufort C, Soeldner JS, Eisenbarth G, Lindgren F, Sundquist G, Lernmark $\AA$ (1987) Antibodies to a Mr 64000 human islet cell antigen precede the clinical onset of insulin-dependent diabetes. J Clin Invest 79: 926-934

15. Srikanta S, Ganda OP, Rabizadeh D, Soeldner JS, Eisenbarth GS (1985) First degree relatives of patients with Type 1 diabetes mellitus Islet-cell antibodies and abnormal insulin secretion. N Engl J Med 313: 461-464

16. Powers AC, Eisenbarth GS (1985) Autoimmunity to islet cells in diabetes mellitus. Ann Rev Med 36: 533-544

17. Spinas GA, Hansen BS, Linde S, Kastern W, Mølvig J, MandrupPoulsen T, Dinarello CA, Nielsen JH, Nerup J (1987) Interleukin 1 dose-dependently affects the biosynthesis of (pro)insulin in isolated rat islets of Langerhans. Diabetologia 30:474-480

18. Srikanta S, Ganda OP, Eisenbarth GS, Soeldner JS (1983) Isletcell antibodies in monozygotic triplets and twins initially discordant for Type 1 diabetes mellitus. N Engl J Med 308: 322-325

19. Srikanta S, Ricker AT, McGulloch DK, Soeldner JS, Eisenbarth GS, Palmer JP (1986) Autoimmunity to insulin, beta cell dysfunction and development of insulin-dependent diabetes mellitus. Diabetes 35: 139-142

20. Köhne $G$ (1941) Über die Beziehungen der Friedreichschen Ataxie zum Diabetes mellitus. Deutsch Med Wochenschr 67: $177-179$

21. James TN, Cobbs BW, Coghlan HC, McCoy WC, Fisch C (1987) Coronary disease, cardioneuropathy and conduction abnormalities in the cardiomyopathy of Friedreich's ataxia. Br Heart $\mathbf{J}$ 57: 446-457

22. Khan RI, Andermann E, Fantus GI (1986) Glucose intolerance in Friedreich's ataxia: Association with insulin resistance and decreased insulin binding. Metabolism 35: 1017-1023

23. Tolis G, Metha A, Andermann E, Harvey C, Barbeau A (1980) Friedreich's ataxia and oral glucose tolerance. Can J Neurol Sci 7: $397-400$

Received: 8 November 1988

and in revised form: 13 March 1989

Dr. E. J.Schoenle

University Children's Hospital

Steinwiesstraße 75

CH-8032 Zuerich

Switzerland 